Natural Hazards and Earth System Sciences, 5, 971-977, 2005

SRef-ID: 1684-9981/nhess/2005-5-971

European Geosciences Union

(C) 2005 Author(s). This work is licensed

under a Creative Commons License.

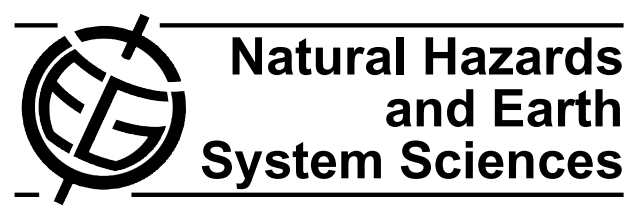

\title{
A debris-flow monitoring devices and methods bibliography
}

\author{
Y. Itakura ${ }^{1}$, H. Inaba ${ }^{2}$, and T. Sawada ${ }^{3}$ \\ ${ }^{1}$ Shiga University, Otsu, Shiga 520-0862, Japan \\ ${ }^{2}$ Kyoto Institute of Technology, Matsugasaki, Kyoto 606-0962, Japan \\ ${ }^{3}$ DPRI Hotaka, Kyoto University, Nakao, Gifu 506-1422, Japan
}

Received: 26 July 2005 - Revised: 15 November 2005 - Accepted: 15 November 2005 - Published: 1 December 2005

Part of Special Issue "Documentation and monitoring of landslides and debris flows for mathematical modelling and design of mitigation measures"

\begin{abstract}
Debris-flow monitoring has two functions, warning and modeling. The warning function includes the following parameters: occurrence prediction and detection, proximity sensing, and discharge-estimation. The parameters obtained from debris-flow measurements can deduce a numerical model for creating a hazard map and designing various types of control structures to mitigate the hazards. Many devices and methods of monitoring are tabulated here for comparative study. Some of them are in operation. Advanced comparative studies lead to an improvement in debris-flow monitoring, an integrated system that can be applied to any torrent, and a breakthrough in future developments.
\end{abstract}

\section{Introduction}

Monitoring debris-flow torrents is essential to prevent and mitigate these hazards. A number of monitoring devices and methods have been developed: for example, seismometers (Okuda et al., 1979; Arattano, 1999, and many others), ground vibration sensors (Zhang, 1993; Itakura et al., 1997, 2000a; Itakura and Sawada, 2003; Hurlimann et al., 2003, and many others), or methods to measure the velocity of debris-flow with image processing techniques (Inaba et al., 1997; Uddin et al., 1999; Arattano and Grattoni, 2000). These sensors are useful to detect debris-flow, to make discharge estimates, and to measure the velocity of temporal variations and spatial distributions. However, it is sometimes unclear whether the sensors have sufficient signal to noise $(\mathrm{S} / \mathrm{N})$ ratio to detect debris-flow events or whether the measurements are accurate enough to be used for the verification of numerical simulation models. A number of studies involving debris-flow monitoring devices and methods published over the last ten years are compiled here to compare their usefulness and to improve the monitoring with high performance.

Correspondence to: Y. Itakura

(itakura@sue.shiga-u.ac.jp)
Monitoring can warn of impending disasters and promote understanding of debris-flow as well as test computer models to predict future disasters. Some functions such as: prediction and detection of debris-flow, proximity sensing, and discharge-estimates are necessary for warning purposes. The performance of each device and method dominates its practical use in the respective torrent. On the other hand, the objective of modeling is to create a hazard map and/or to design some structures for use in the torrent to mitigate the hazards. The data obtained from debris-flow monitoring such as of the parameters of the flow and the meteorological parameters can contribute to the value of this type of modeling.

Tables 1 and 2 list a number of devices and methods, which may be used to obtain the warning and modeling information. These are divided into three groups. The first is Eulerian observation to detect the debris-flow and obtain its parameters at a stationary point in the field. The second is Lagrangian observation to estimate the parameters by moving with the debris-flow. The third gathers the parameters from satellite image processing of the remote sensing data and the field survey before and after an event. The comparative tables may lead to an improvement in future debris-flow monitoring.

\section{Comparative tables}

Table 1 summarizes the devices and methods used to warn of possible debris-flow events. Many operate in real-time in the field. They are further differentiated with respect to function and performance. The function subcategory includes information relative to prediction, detection, proximity sensing, and discharge-estimation of a debris-flow event while the performance subcategory provides contact or non-contact data, reuse after an easy reset, working in bad weather, active or passive and low power consumption. The definitions of the symbols in Table 1 are as follows: $\bigcirc$, "useful", signifies that the devices and methods have been applied to field use; $\triangle$, "possible", is useful in the laboratory only but may 
Table 1. Monitoring devices and methods function and performance parameters for debris-flow warning prediction.

\begin{tabular}{|c|c|c|c|c|c|c|c|c|c|}
\hline \multirow[b]{2}{*}{ Devices and methods } & \multicolumn{4}{|c|}{ functions } & \multicolumn{4}{|c|}{ performance } & \multirow[b]{2}{*}{$\begin{array}{c}\text { low } \\
\text { power }\end{array}$} \\
\hline & $\begin{array}{l}\text { occurrence } \\
\text { prediction }\end{array}$ & $\begin{array}{l}\text { occurrence } \\
\text { detection }\end{array}$ & $\begin{array}{l}\text { proximity } \\
\text { sensing }\end{array}$ & $\begin{array}{l}\text { discharge } \\
\text { estimation }\end{array}$ & $\begin{array}{c}\text { contact }(\mathrm{C}) \text { or } \\
\text { non-contact }(\mathrm{NC})\end{array}$ & $\begin{array}{l}\text { reuse } \\
\text { /reset }\end{array}$ & $\begin{array}{l}\text { working in } \\
\text { bad weather }\end{array}$ & $\begin{array}{c}\text { active }(\mathrm{A}) \text { or } \\
\text { passive }(\mathrm{P})\end{array}$ & \\
\hline \multicolumn{10}{|l|}{ I. Euler group } \\
\hline 1. rain gauge & $\bigcirc$ & $x$ & $x$ & $x$ & $\mathrm{NC}$ & $\mathrm{Y}$ & $\mathrm{Y}$ & $\mathrm{P}$ & $\mathrm{Y}$ \\
\hline 2. strain gauge & $\triangle$ & $\bigcirc$ & $\bigcirc$ & $\triangle$ & $\mathrm{NC}$ & $\mathrm{Y}$ & $\mathrm{Y}$ & $\mathrm{P}$ & $\mathrm{Y}$ \\
\hline 3. ultrasonic gauge & - & $\bigcirc$ & $\bigcirc$ & $\bigcirc$ & $\mathrm{NC}$ & $\mathrm{Y}$ & $\mathrm{Y}$ & A & $\mathrm{Y}$ \\
\hline 4. wire sensor & $x$ & $\bigcirc$ & $\bigcirc$ & $\triangle$ & $\mathrm{C}$ & $\mathrm{Y} / \mathrm{N}$ & $\mathrm{Y}$ & $\mathrm{P} / \mathrm{A}$ & $\mathrm{Y} / \mathrm{N}$ \\
\hline 5. pressure sensor & - & $\triangle$ & $\triangle$ & $\triangle$ & $\mathrm{C}$ & $\mathrm{Y}$ & Y & $\mathrm{P}$ & $\mathrm{Y}$ \\
\hline \multicolumn{10}{|c|}{ 6. ground vibration sensor } \\
\hline (a) microphone & - & $\triangle$ & $\bigcirc$ & $\bigcirc$ & $\mathrm{NC}$ & $\mathrm{Y}$ & $\mathrm{Y}$ & $\mathrm{P}$ & $\mathrm{Y}$ \\
\hline (b) seismometer & - & $\triangle$ & $\bigcirc$ & 0 & $\mathrm{NC}$ & $\mathrm{Y}$ & $\mathrm{Y}$ & $\mathrm{P}$ & $\mathrm{Y}$ \\
\hline (c) moving coil & - & $\triangle$ & $\bigcirc$ & $\bigcirc$ & $\mathrm{NC}$ & $\mathrm{Y}$ & $\mathrm{Y}$ & $\mathrm{P}$ & $\mathrm{Y}$ \\
\hline (d) piezoelectric & - & $\triangle$ & $\bigcirc$ & $\bigcirc$ & $\mathrm{NC}$ & $\mathrm{Y}$ & $\mathrm{Y}$ & $\mathrm{P}$ & $\mathrm{Y}$ \\
\hline \multicolumn{10}{|l|}{ 7. image processing } \\
\hline (a) spatial filtering & $\times$ & $\triangle$ & $\bigcirc$ & $\triangle$ & $\mathrm{NC}$ & $\mathrm{Y}$ & $* 1$ & $\mathrm{P}$ & $* 2$ \\
\hline (b) MPEG method & $x$ & $\triangle$ & $\bigcirc$ & $\triangle$ & $\mathrm{NC}$ & $\mathrm{Y}$ & $* 1$ & $\mathrm{P}$ & $* 2$ \\
\hline (c) STD method & $x$ & $\triangle$ & $\bigcirc$ & $\triangle$ & $\mathrm{NC}$ & $\mathrm{Y}$ & $* 1$ & $\mathrm{P}$ & $* 2$ \\
\hline (d) correlation & $x$ & $\triangle$ & $\bigcirc$ & $\triangle$ & $\mathrm{NC}$ & $\mathrm{Y}$ & $* 1$ & $\mathrm{P}$ & $* 2$ \\
\hline 8. radar & - & $\triangle$ & $\bigcirc$ & $\triangle$ & $\mathrm{NC}$ & $\mathrm{Y}$ & $\mathrm{Y}$ & $\mathrm{A}$ & $\mathrm{N}$ \\
\hline 9. bucket/load cell & $x$ & $x$ & $x$ & $\triangle$ & $\mathrm{C}$ & $\mathrm{N}$ & Y & $\mathrm{P}$ & $\mathrm{N}$ \\
\hline 10. Infrasonic sensor & - & $\bigcirc$ & $\bigcirc$ & - & $\mathrm{NC}$ & $\mathrm{Y}$ & Y & $\mathrm{P}$ & $\mathrm{Y}$ \\
\hline \multicolumn{10}{|l|}{ II. Lagrange group } \\
\hline 1. accelerometer & - & $\triangle$ & $\triangle$ & - & $\mathrm{C}$ & $\mathrm{N}$ & $\mathrm{Y}$ & $\mathrm{P}$ & $* 3$ \\
\hline 2. integrated sensor & - & $\bigcirc$ & $\bigcirc$ & $\triangle$ & $\mathrm{C}$ & $\mathrm{N}$ & $\mathrm{Y}$ & $\mathrm{P}$ & $* 3$ \\
\hline
\end{tabular}

$\bigcirc$ useful, $\triangle$ possible, $\times$ impossible, - to be investigated

$* 1$ difficult in fog, $* 2$ with a computer system, *3 demand of high power for sending the signal

Abbreviations: MPEG; moving picture-cording experts group, STD; spatio-temporal derivative

Table 2. Monitoring devices and methods flow and meteorological parameters for debris-flow modeling.

\begin{tabular}{|c|c|c|c|c|c|c|c|c|c|c|c|c|}
\hline \multirow[b]{2}{*}{ Devices and methods } & \multicolumn{9}{|c|}{ parameters of the flow } & \multicolumn{3}{|c|}{ meteorological parameters } \\
\hline & depth & velocity & $\begin{array}{l}\text { vector } \\
\text { velocity }\end{array}$ & discharge & $\begin{array}{l}\text { impact } \\
\text { force }\end{array}$ & viscosity & $\begin{array}{l}\text { particle } \\
\text { size }\end{array}$ & $\begin{array}{l}\text { accumulated } \\
\text { volume }\end{array}$ & $\begin{array}{l}\text { sediment } \\
\text { yield }\end{array}$ & $\begin{array}{c}\text { rainfall } \\
\text { intensity }\end{array}$ & $\begin{array}{l}\text { accumulated } \\
\text { rainfall }\end{array}$ & $\begin{array}{l}\text { historical } \\
\text { rainfall }\end{array}$ \\
\hline \multicolumn{13}{|l|}{ I. Euler group } \\
\hline 1. rain gauge & $\times$ & $\times$ & $x$ & $\times$ & $\times$ & - & $x$ & $\times$ & $\times$ & $\bigcirc$ & $\bigcirc$ & $\bigcirc$ \\
\hline 2. strain gauge & $\times$ & $\times$ & $x$ & $x$ & $\bigcirc$ & $\times$ & $x$ & $\triangle$ & - & $\times$ & $x$ & $\times$ \\
\hline 3. ultrasonic gauge & $\bigcirc$ & $\bigcirc$ & - & $\bigcirc$ & $\times$ & - & $x$ & $\triangle$ & - & - & - & - \\
\hline 4. wire sensor & $\bigcirc$ & $\bigcirc$ & $x$ & - & $\times$ & $x$ & $x$ & - & - & $x$ & $x$ & $x$ \\
\hline 5. pressure sensor & $\triangle$ & $\triangle$ & - & $\triangle$ & $\bigcirc$ & - & - & $\triangle$ & - & - & - & $x$ \\
\hline \multicolumn{13}{|l|}{ 6. ground vibration sensor } \\
\hline (a) microphone & $\triangle$ & $\triangle$ & $x$ & $\bigcirc$ & - & $\times$ & $\triangle$ & $\times$ & $\times$ & $\times$ & $\times$ & $\times$ \\
\hline (b) seismometer & $\triangle$ & $\bigcirc$ & $x$ & $\bigcirc$ & - & $\times$ & - & $\times$ & $\times$ & $\times$ & $x$ & $\times$ \\
\hline (c) moving coil & $\triangle$ & $\triangle$ & $x$ & $\bigcirc$ & - & $x$ & $\triangle$ & $\times$ & $x$ & $x$ & $x$ & $x$ \\
\hline (d) piezoelectric & $\triangle$ & $\triangle$ & $x$ & $\bigcirc$ & - & $x$ & - & $x$ & $x$ & $x$ & $\times$ & $x$ \\
\hline \multicolumn{13}{|l|}{ 7. image processing } \\
\hline (a) spatial filtering & - & $\bigcirc$ & $\bigcirc$ & - & $x$ & $x$ & $\triangle$ & - & $x$ & $x$ & $\times$ & $x$ \\
\hline (b) MPEG method & $\triangle$ & - & - & $\triangle$ & $x$ & $x$ & $x$ & $x$ & $x$ & $x$ & $\times$ & $x$ \\
\hline (c) STD method & - & $\bigcirc$ & $\bigcirc$ & - & $x$ & $x$ & $x$ & $x$ & $x$ & $x$ & $\times$ & $x$ \\
\hline (d) correlation & $\triangle$ & $\bigcirc$ & $\bigcirc$ & $\triangle$ & $x$ & $x$ & $\triangle$ & $\triangle$ & $x$ & $x$ & $x$ & $x$ \\
\hline (e) AR synthetic model & $x$ & $\times$ & $x$ & - & $x$ & $x$ & $\bigcirc$ & - & $x$ & $x$ & $\times$ & $\times$ \\
\hline 8. radar & - & $\bigcirc$ & $\triangle$ & - & $x$ & - & - & - & - & $\bigcirc$ & $\bigcirc$ & $\bigcirc$ \\
\hline 9. bucket/load cell & - & $x$ & $x$ & $\bigcirc$ & - & $\triangle$ & $\triangle$ & $\triangle$ & - & - & - & $x$ \\
\hline \multicolumn{13}{|l|}{ II. Lagrange group } \\
\hline 1. accelerometer & - & $\triangle$ & $\triangle$ & - & - & $\times$ & $x$ & $x$ & $x$ & $x$ & $x$ & $x$ \\
\hline 2. integrated sensor & $\triangle$ & $\bigcirc$ & $\bigcirc$ & $\triangle$ & - & $\bigcirc$ & - & $x$ & $x$ & $x$ & $\times$ & $x$ \\
\hline 3. GPS sensor & - & - & - & - & - & $x$ & $x$ & $\times$ & $x$ & $\times$ & $\times$ & $\times$ \\
\hline \multicolumn{13}{|c|}{ III. Satellite/Field survey group } \\
\hline 1. satellite image analysis & $\triangle$ & $\triangle$ & - & $\triangle$ & $x$ & - & - & $\bigcirc$ & $\bigcirc$ & $\times$ & $\times$ & $\times$ \\
\hline 2. range finder & $\triangle$ & - & $x$ & $\triangle$ & $x$ & $x$ & $x$ & $\triangle$ & $\triangle$ & $x$ & $x$ & $x$ \\
\hline 3. electrical sensing & - & $x$ & $x$ & - & - & $\triangle$ & $\triangle$ & $\triangle$ & $\triangle$ & - & - & $x$ \\
\hline 4. sampler/measure & $x$ & $x$ & $x$ & $x$ & $x$ & - & $\bigcirc$ & $\bigcirc$ & $\bigcirc$ & $x$ & $\times$ & $x$ \\
\hline
\end{tabular}

$\bigcirc$ useful, $\triangle$ possible, $\times$ impossible, - to be investigated

Abbreviations: MPEG; moving picture-coding experts group, STD; spatio temporal derivative, AR; auto regressive 
Table 3. Debris-flow monitoring bibliography.

\begin{tabular}{|c|c|}
\hline devices and methods & references \\
\hline \multicolumn{2}{|l|}{ I. Euler group } \\
\hline 1. rain gauge & $\begin{array}{l}\text { Jingwu (1989), Deganutti et al. (2000), Marchi et al. (2002), Fan et al. (2003), Wieczorek et al. (2003), } \\
\text { Hurlimann et al. (2003) }\end{array}$ \\
\hline 2. strain gauge & Zhang (1993) and popular \\
\hline 3. ultrasonic gauge & $\begin{array}{l}\text { Pierson (1986), Zhicheng and Ringhua (1989), Zhang (1993), Arattano et al. (1997), } \\
\text { Arattano and Moia (1999), Genevois et al. (2000), Marchi et al. (2002) }\end{array}$ \\
\hline 4. wire sensor & popular \\
\hline 5. pressure sensor & Genevois et al. (2000) \\
\hline \multicolumn{2}{|l|}{ 6. ground vibration sensor } \\
\hline (a) microphone & Taniguchi et al. (1992), Itakura et al. (1997, 2000a), Itakura and Sawada (2003) \\
\hline (b) seismometer & Okuda et al. (1979), Suwa and Okuda (1985), Ewert et al. (1993), Arattano (1999), \\
\hline & Arattano and Moia (1999), Suwa et al. (2000), Arattano (2000), Genevois et al. (2000), \\
\hline & Marchi et al. (2002), Arattano (2003) \\
\hline (c) moving coil & Pierson (1995), Huang et al. (2003) \\
\hline (d) piezoelectric & $\begin{array}{l}\text { Banziger and Burch (1990), Zhang (1993), Rickenmann (1994), Ishikawa and Ishizuka (1995), } \\
\text { Rickenmann et al. (1998), Hurlimann et al. (2003) }\end{array}$ \\
\hline \multicolumn{2}{|l|}{ 7. image processing } \\
\hline (a) spatial filtering & Itakura et al. $(1985,1989,1991)$, Uddin et al. $(1998,1999)$, Genevois et al. (2001), Itakura (2003) \\
\hline (b) MPEG method & Koyama et al. (2000) \\
\hline (c) STD method & Inaba et al. (1997, 2000), Uddin et al. (2001) \\
\hline (d) correlation & $\begin{array}{l}\text { Arattano and Marchi (2000); Arattano and Grattoni (2000), Uddin et al. (2002), Marchi et al. (2002), } \\
\text { Lavigne et al. (2003), Zhang and Chen (2003) }\end{array}$ \\
\hline (e) AR synthetic model & Inaba and Itakura (2003) \\
\hline 8. radar & YDK (2002) \\
\hline 9. bucket/loadcell & Miyamoto et al. (1992), Laronne et al. (1992) \\
\hline 10. Infrasonic sensor & Zhang et al. (2004) \\
\hline \multicolumn{2}{|l|}{ II. Lagrange group } \\
\hline 1. accelerometer & Itakura et al. (2000b) \\
\hline 2. Integrated sensor & Hanisch et al. (2003) \\
\hline 3. GPS sensor & Aono et al. (1999) \\
\hline \multicolumn{2}{|c|}{ III. Satellite/Field Survey group } \\
\hline 1. Satellite image analysis & $\begin{array}{l}\text { Kawamura and Tsujiko (1998), Parise (2001), Qi et al. (2001), Hubl and Steinwendtner (2001), } \\
\text { Polemio and Petrucci (2001) }\end{array}$ \\
\hline 2. range finder & Asano et al. (2002) \\
\hline 3. electrical sensing & Godio and Bottino (2001) \\
\hline 4. sampler/measure & $\begin{array}{l}\text { Suwa and Okuda (1985), Pierson (1986), Bogen (1992), De Jong (1992), } \\
\text { Moscariello and Deganutti (2000), Rickenmann (2001) }\end{array}$ \\
\hline
\end{tabular}

Abbreviations: MPEG; moving picture-coding experts group, STD; spatio temporal derivative, AR; auto regressive

be available for field use in the future; $\times$, "impossible", is not possible in principle; and -, "to be investigated", means that a prototype sensor has not been developed yet, but its feasibility needs to be investigated.

Table 2 summarizes the parameters necessary to make a computer model for debris-flow. The following parameters should be measured: (1) the flow parameters are depth, velocity, vector velocity, discharge, impact force, viscosity, particle size, accumulated volume, and sediment yield and (2) the meteorological parameters are rainfall intensity, accumulated rainfall, and historical data on rainfall. Although the meteorological parameters are not obtained by direct mon- itoring of debris-flow, these are important for modeling as shown in Table 2. Other basic parameters concerned with the catchments are required for modeling. These are the length and slope of the channel and the drainage area. Those parameters are an indirect part of debris-flow monitoring, so they are not shown in Table 2 . The definitions of the symbols in Table 2 are the same as for Table 1. The parameters in Table 2 are compared qualitatively without quantitative comparison at the present time. References in Tables 1 and 2 are summarized in Table 3. Those references are concerned with not only debris-flow but also the related phenomena, for example, sediment transport, rock-fall, and flood-flow. These 
related references are intended to complement the comparative study of debris-flow monitoring.

\section{Comments and conclusion}

The comparative analyses of the data in Tables 1 and 2 shows practical use availability of many devices and methods in spite of qualitative comparison. Table 1 shows a number of devices and methods available to warn about the proximity sensing of debris-flows. However, few occurrence prediction sensors are available. A rain gauge is often useful to predict the possible occurrence of debris-flow in spite of the limitation of indirect observation. Quick discharge estimation is also desirable to warn of the extent of the debris-flow. Table 2 shows that the number of devices and methods are limited to obtain parameters useful for modeling purposes. Only one or two devices and/or methods present the parameters of debrisflow with moderately accurate data. Therefore, it is desired to achieve high accuracy of each parameter or to develop an integrated monitoring system.

There are some useful statistical approaches for predicting debris-flow occurrence, estimating the discharge amount, and making a hazard map. These methods are a statistical analysis of GIS data, a risk analysis and a statistical prediction analysis of previous data useful for warning and modeling by assisting the monitoring devices and methods shown in Tables 1 and 2 (De Roo et al., 1994; Downward et al., 1994; Becht and Rieger, 1997; Tanabashi, 1998; Franzi and Bianco, 2001; Machida, 2001; Temesgen et al., 2001; D'Agostino and Marchi, 2001; De Joode and Van Steijn, 2003).

Many researchers have reported an integrated observation method (Zhang, 1993; Marchi et al., 2002; Hurlimann et al., 2003). The authors are also planning a combination system that consists of an accelerometer sensor (Itakura et al. 2000b) and an acoustic sensor (Itakura et al., 2000a) as well as image processing methods (Inaba et al., 1997; Uddin et al., 1999). A cooperative network of image processing is also included in the concept. In collaboration with many researchers (Arattano and Marchi, 2000; Arattano and Grattoni, 2000; Genevois et al., 2001; Koyama et al., 2000; Inaba et al., 1997, 2000; Itakura, 2003; Marchi et al., 2002; Uddin et al., 1998, 1999, 2001, 2002) the software programs can be developed and utilized to process the debris-flow video images. This collaborative effort is expected to contribute to the development of more effective image-processing software and to maximize the information available from debrisflow images taken through out the world.

The devices and methods shown in Tables 1 and 2 are utilized mainly for the debris-flow that often occurs after heavy rains. Some devices and methods are needed to monitor debris-flows related directly to other events such as rapid melting glaciers due to global warming or a rapid melting snow caused by volcanic eruption. As debris-flows occur in different torrents due to different causes, the monitoring is required to be useful to all events in the world.
It is hoped that the current study is the first step in debrisflow monitoring improvement and the next step may be to develop international collaboration. Researchers in debris-flow monitoring may organize an association of worldwide collaboration (Itakura, 2005), which will contribute to understanding the feasibility of sensors to fit the causes of debris-flow. A breakthrough of debris-flow monitoring is also expected through continuous studies.

Acknowledgements. The authors would like to acknowledge the help received from many researchers in debris-flow monitoring field. The authors also would like to thank all participants in the workshop on debris-flow monitoring organized by the Swiss Federal Office for Water and Geology at Bern-Ittigen, Switzerland, on 5-6 November 2001 for their helpful efforts to formulate the comparative tables presented in this paper. The authors also wish to thank all participants for the useful discussion in the natural hazards section of the European Geosciences Union (EGU) General Assembly.

Edited by: M. Arattano

Reviewed by: L. Marchi and two referees

\section{References}

Aono, T., Fujii, K., and Hatsumoto, S.: Positioning of a vehicle on undulating ground using GPS and internal sensors, Trans. Soc. Instrum. Control Eng., 35, 1004-1011, (in Japanese), 1999.

Arattano, M., Deganutti, A. M., and Marchi, L.: Debris flow monitoring activities in an instrumented watershed on the Italian Alps, in: Debris-Flow Hazards Mitigation: Mechanics, Prediction, and Assessment, edited by: Chen, C. L., Proc. first intern. conf., San Francisco, USA, 7-9 August, ASCE, New York, 1997, 506-515, 1997.

Arattano, M.: On the use of seismic detectors as monitoring and warning systems for debris-flows, Nat. Haz., 20, 197-213, 1999.

Arattano, M. and Moia, F.: Monitoring the propagation of a debris flow along a torrent, Hydrol. Sci., 44 811-823, 1999.

Arattano, M. and Grattoni, P.: Using a fixed video camera to measure debris-flow surface velocity, in: Debris-Flow Hazards Mitigation: Mechanics, Prediction, and Assessment, eidted by: Wieczorek, G. F. and Naeser, N. D., Proc. 2nd Intern. Conf., Taipei, Taiwan, 16-18 August 2000, Rotterdam, Balkema Press, 273-281, 2000.

Arattano, M. and Marchi, L.: Video-derived velocity distribution along a debris flow surge, Phys. Chem. Earth (B), 25, 781-784. 2000.

Arattano, M.: On debris flow front evolution along a torrent, Phys. Chem. Earth (B), 25, 733-740, 2000.

Arattano, M.: Monitoring the presence of the debris-flow front and its velocity through ground vibration detectors, in: Debris-Flow Hazards Mitigation: Mechanics, Prediction, and Assessment, edited by: Rickenmann, D. and Wieczorek, G. F., Proc. 3rd Intern. Conf., Davos, Switzerland, 10-12 Sept. 2003, Rotterdam, Mill Press, 2003.

Asano, H., Ishii, Y., Tsunaki, R., and Osanai, N.: Applicability of 3D laser scanner for measurement of landslide movement, Civil Eng. J., 44, 24-29 (in Japanese), 2002.

Banzinger, R. and Burch, H.: Acoustic sensors (hydrophones) as indicators for bed load transport in a mountain torrent, Proc. Hy- 
drology in Mountainous Regions, Lausanne, Switzerland, August 1990, 207-214, Publication No. 193, 207-214, 1990.

Becht, M. and Rieger, D.: Spatial and temporal distribution of debris-flow occurrence on slopes in the Eastern Alps, in: DebrisFlow Hazards Mitigation: Mechanics, Prediction, and Assessment, edited by: Chen, C. L., Proc. First Intern. Conf., San Francisco, USA, 7-9 August 1997, New York, ASCE, 516-529, 1997.

Bogen, J.: Monitoring grain size of suspended sediments in river, in: Erosion and Sediment Transport Monitoring Programmes in River Basin, edited by: Bogen, J., Walling, D. E., and Day, T., Proc. Intern. Symp., Oslo, Norway, 24-28 August 1992, 183190, IAHS Publication No. 210, 1992.

D'Agostino, V. and Marchi, L.: Debris flow magnitude in the eastern Italian Alps: Data collection and analysis, Phys. Chem. Earth (C), 26, 657-663, 2001

Deganutti, A. M., Marchi, L., and Arattano, M.: Rainfall and debris-flow occurrence in the Moscardo basin (Italian Alps), in: Debris-Flow Hazards Mitigation: Mechanics, Prediction, and Assessment, edited by: Wieczorek, G. F. and Naeser, N. D., Proc. 2nd Intern. Conf., Taipei, Taiwan, 16-18 August 2000, Rotterdam, Balkema Press, 67-72, 2000.

De Jong, C.: Measuring changes in micro and macro roughness on mobile gravel beds, in: Erosion and Sediment Transport Monitoring Programmes in River Basin, edited by: Bogen, J., D.E. Walling, D. E., and T. Day, T., Proc. Intern. Symp., Oslo, Norway, 24-28 August 1992, IAHS Publication No. 210, 31-40, 1992.

De Joode, A. and Van Steijn, H.: PROMOTOR-df: a GIS-based simulation model for debris-flow hazard prediction, in: DebrisFlow Hazards Mitigation: Mechanics, Prediction, and Assessment, edited by: Rickenmann, D. and Wieczorek, G. F., Proc. 3rd Intern. Conf., Davos, Switzerland, 10-12 Sept. 2003, Rotterdam, Mill Press, 1173-1184, 2003.

De Roo, A. P. J., Wesseling, C. G., Cremers, N. H. D. T., Ritsema, C. J., and Van Oostinie, K.: LISEM: a new physically-based hydrological and soil erosion model in a GIS-environment, theory, and implementation, in: Variability in Stream Erosion and Sediment Transport, edited by: Olive, L. J., Loughran, R. J., and Kesby, J. A., Proc. Intern. Symp., Canberra, Australia, 12-16 Dec. 1994, IAHS Publication No. 224, 439-448, 1994.

Downward, S. R., Gurnell, A. M., and Brookes, A.: A methodology for quantifying river channel planform change using GIS, in: Variability in Stream Erosion and Sediment Transport, edited by: Olive, L. J., Loughran, R. J., and Kesby, J. A., Proc. Intern. Symp., Canberra, Australia, 12-16 Dec. 1994, IAHS Publication No. 224, 449-456, 1994.

Ewert, J. W., Murray, T. L., Lockhart, A. B., and Miller, C. D.: Preventing volcanic catastrophe; The US International Volcano Disaster Assistance Program, Earthquakes and Volcano, 24, 270291, 1993.

Fan, J.-C., Liu, C.-H., Wu, M.-F., and Yu, S.K.: Determination of critical rainfall thresholds for debris-flow occurrence in central Taiwan and their revision after the 1999 Chi-Chi great earthquake, in: Debris-Flow Hazards Mitigation: Mechanics, Prediction, and Assessment, edited by: Rickenmann, D. and Wieczorek, G. F, Proc. 3rd Intern. Conf., Davos, Switzerland, 10-12 Sept. 2003, Rotterdam, Mill Press, 103-114, 2003.

Franzi, L. and Bianco, G.: A statistical method to predict debris flow deposited volumes on a debris fan, Phys. Chem. Earth (C), 26, 683-688, 2001.
Genevois, R., Tecca, P. R., Breti, M., and Simoni, A.: Debris-flow in the Doromites: Experimental data from a monitoring system, in: Debris-Flow Hazards Mitigation: Mechanics, Prediction, and Assessment, edited by: Wieczorek, G. F. and Naeser, N. D., Proc. 2nd Intern. Conf., Taipei, Taiwan, 16-18 August 2000, Rotterdam, Balkema Press, 283-291, 2000.

Genevois, R., Gaigaro, A., and Tecca, P. R.: Image analysis for debris flow properties estimation, Phys. Chem. Earth (C), 26, 623631, 2001.

Godio, A. and Bottino, G.: Electrical and electromagnetic investigation for landslide characterization, Phys. Chem. Earth (C), 26, 705-710, 2001.

Hanisch, J., Ergenzinger, P., and Bonte, M.: Dumpling-an "intelligent" boulder for studying internal processes of debris flows, in: Debris-Flow Hazards Mitigation: Mechanics, Prediction, and Assessment, edited by: Rickenmann, D. and Wieczorek, G. F., Proc. 3rd Intern. Conf., Davos, Switzerland, 10-12 Sept. 2003, Rotterdam, Mill Press, 843-849, 2003.

Huang, C.-J., Yin, H.-Y., and Shieh, C.-L.: Experimental study of the underground sound generated by debris flows, in: DebrisFlow Hazards Mitigation: Mechanics, Prediction, and Assessment, edited by: Rickenmann, R. and Wieczorek, G. F., Proc. 3rd Intern. Conf., Davos, Switzerland, 10-12 Sept. 2003, Rotterdam, Mill Press, 743-753, 2003.

Huble, J. and Steinwendtner, H.: Two-dimensional simulation of two viscous debris flows in Austria, Phys. Chem. Earth (C), 26, 639-644, 2001.

Hurlimann, M., Rickenmann, D., and Graf, D.: Field and monitoring data of debris-flow events in the Swiss Alps, Canadian Geotechnical Journal, 40, 161-175, 2003.

Inaba, H., Uddin, M. S., Itakura, Y., and Kasahara, M.: Surface velocity vector field measurement of debris flow based on spatio temporal derivative space method, in: Debris-Flow Hazards Mitigation: Mechanics, Prediction, and Assessment, edited by: Chen, C. L., Proc. First Intern. Conf., San Francisco, USA, 7-9 August 1997, New York, ASCE, 757-766, 1997.

Inaba, H., Itakura, Y., and Kasahara, M.: Surface velocity computation of debris-flows by vector field Measurements, Phys. Chem. Earth (B), 25, 741-744, 2000.

Inaba, H. and Itakura, Y.: Notes on the modeling of debris-flow surface images, in: Debris-Flow Hazards Mitigation: Mechanics, Prediction, and Assessment, edited by: Rickenmann, D. and Wieczorek, G. F., Proc. 3rd Intern. Conf., Davos, Switzerland, 10-12 Sept. 2003, Rotterdam, Mill Press, 755-765, 2003.

Ishikawa, Y. and Ishizaki, T.: System for measuring debris flow ground vibrations at Mt. Unzen, Proc. 3rd PWRI-USGS Workshop on Hydrology, Tsukuba, Japan, 31 Jan.-1 Feb. 1995, PERI No. 3373, 31-37, 1995.

Itakura, Y., Ogawa, K., Suwa, H., and Mizuhara, K.: Trend and fluctuations of the surface-velocity of Debris-flow measured by a non-contact speed sensor with a spatial filter, in: Fluid Control and Measurement, edited by: Harada, M., Proc Intern. Symp., Tokyo, Japan, 2-6 September 1985, New York, Pergamon Press, 781-786, 1985.

Itakura, Y. and Suwa, H.: Measurement of surface velocity of debris flows by spatial filtering velocimetry, in: Landslides and DebrisFlows, edited by: Tochiki, S., Proc. The Japan-China Symp., 3 Oct., Niigata and 5 Oct., Tokyo, Japan, 1989, published by The Japan Landslide Soc. and The Japan Soc. Erosion Control Eng., 199-203, 1989.

Itakura, Y., Takeuchi, M., Kasahara, M., and Ogura, H.: Spatial filtering velocimetry: computer simulation by the artificial random 
moving image and application to the measurement of the surface velocity of debris-flow, Trans. Soc. Instrument Control Eng., 27, 1092-1098 (in Japanese), 1991.

Itakura, Y., Koga, Y., Takahama, J., and Nowa, Y.: Acoustic detection sensor for debris-flow, in: Debris-Flow Hazards Mitigation: Mechanics, Prediction, and Assessment, edited by: Chen, C. L., Proc. First Intern. Conf., San Francisco, USA, 7-9 August 1997, New York, ASCE, 747-756, 1997.

Itakura, Y., Fujii, N., and Sawada, T.: Basic characteristics of ground vibration sensors for the detection of debris-flow, Phys. Chem. Earth (B), 25, 717-720, 2000a.

Itakura, Y., Kitajima, T., Endo, K., and Sawada, T.: A new double dual-axes accelerometer debris-flow detection system, in: Debris-Flow Hazards Mitigation: Mechanics, Prediction, and Assessment, edited by: Wieczorek, G. F. and Naeser, N. D., Proc. 2nd Intern. Conf., Taipei, Taiwan, 16-18 August 2000, Rotterdam, Balkema Press, 319-324, 2000b.

Itakura, Y.: Spatial-Filtering Velocimetry, Encyclopedia of Optical Engineering (EOE), doi:10.1081/E-EOE 120009552, 26072617, 2003.

Itakura, Y. and Sawada, T.: An oil-immersed microphone sensor for improved debris-flow detection, in: Debris-Flow Hazards Mitigation: Mechanics, Prediction, and Assessment, edited by: Rickenmann, D. and Wieczorek, G. F., Proc. 3rd Intern. Conf., Davos, Switzerland, 10-12 Sept. 2003, Rotterdam, Mill Press, 863-870, 2003.

Itakura, Y.: Development of debris-flow monitoring technology to mitigate worldwide its disaster, Technology List on Implementation Strategies for Disaster Reduction, one of reports concerned with World Conference on Disaster Reduction, Kobe, Japan, 1822, 2005, A2-FD-01, Japanese Ministry of Education, Culture, Sports, Science and Technology, 2005.

Jingwu, C.: Prediction of rainstorm-induced debris flows, in: Landslides and Debris Flows, edited by: Tochiki, S., Proc. The JapanChina Symp., 3 Oct., Niigata and 5 Oct., Tokyo, Japan, 1989, published by The Japan Landslide Soc. and The Japan Soc. Erosion Control Eng., 183-186, 1989.

Kawamura, M. and Tsujiko, Y.: A GIS approach to the monitoring of damaged mountain slopes using satellite IR images, J. Japan Society for Natural Disaster Science, 17, 279-290, 1998.

Koyama, T., Inaba, H., Itakura, Y., and Kasahara, M.: Detection of debris-flow based on MPEG video, Trans. Soc. Instrum. Control Eng., 36, 1047-1049 (in Japanese), 2000.

Laronne, J. B., Reid, I., Yitshak, Y., and Frostick, L.: Recording bedload discharge in a semiarid channel, Hahal Yatir, Israel, in: Erosion and Sediment Transport Monitoring Programmes in River Basin, edited by: Bogen, J., Walling, D. E., and Day, T. Proc. Intern. Symp., Oslo, Norway, 24-28 August 1992, IAHS Publication No. 210, 79-86, 1992.

Lavigne, F., Tirel, A., and Le Floch, D.: A real-time assessment of lahar dynamics and sediment load based on video-camera recording at Semeru volcano, Indonesia, in: Debris-Flow Hazards Mitigation: Mechanics, Prediction, and Assessment, edited by: Rickenmann, D. and Wieczorek, G. F., Proc. 3rd intern. conf., Davos, Switzerland, 10-12 Sept. 2003, Rotterdam, Mill Press, 871-882, 2003.

Machida, S.: Future Prospect of harmonized utilization with GIS and GPS, Journal of The Remote Sensing Society of Japan, 21, RSSJ Tokyo, 64-71, 2001.

Marchi, L., Arattano, M., and Deganutti, A. M.: Ten years of debrisflow monitoring in the Moscardo Torrent (Italian Alps), Geomorphology, 46, 1-17, 2002.
Miyamoto, K., Kurihara, J., Sawada, T., and Itakura, Y.: A study of field methods for measuring sediment discharge, in: Erosion and Sediment Transport Monitoring Programmes in River Basin, Bogen, J., Walling, D. E., and Day, T., Proc. Intern. Symp., Oslo, Norway, 24-28 August 1992, IAHS Publication No. 210, $107-$ 114, 1992.

Moscariello, A. and Deganutti, A. M.: Sedimentary and hydrologic processes of a debris-flow dominated alluvial fan- Moscardo Fan, Italy, in: Debris-Flow Hazards Mitigation: Mechanics, Prediction, and Assessment, edited by: Wieczorek, G. F. and Naeser, N. D., Proc. 2nd intern. conf., Taipei, Taiwan, 16-18 August 2000, Rotterdam, Balkema Press, 301-309, 2000.

Montgomery, D. R., Schmidt, K. M., Greenberg, H. M., and Dietrich, W. E.: Forest clearing and regional landsliding, Geology, 28, 311-314, 2000.

Okuda, S., Suwa, H., Okunishi, K., Yokoyama, K., Ogawa, K., and Hamana, S.: Synthetic observation on debris-flow, Part 5, Observation at Valley Kamikamihorisawa of Mt. Yakedake in 1978, Annuals of Disaster Prevention Research Institute, Kyoto University, 22B-1, 157-204, (in Japanese), 1979.

Parise, M.: Landslide mapping techniques and their use in the assessment of the landslide hazard, Phys. Chem. Earth (C), 26, 697-703, 2001.

Pierson, T. C.: Flow behavior of channelized debris flows, Mount St. Helens, Washington, in: Hillslope Processes, edited by: Abrahams, A. D., the 16th Annual Geomorphology Symposium, Buffalo, USA, 28-29 Sept. 1985, Allen and Unwin, Boston, 269-296, 1986.

Pierson, T. C.: Joint Study Results; Project on lahar and pyrocrastic flows, Proc. 3 rd PWRI-USGS Workshop on Hydrology, Tsukuba, Japan, 31 Jan.-1 Feb. 1995, PERI No. 3373, 38-44, 1995.

Polemio, M. and Petrucci, O.: Hydrogeological monitoring and image analysis of a mudslide in Southern Italy, Phys. Chem. Earth (C), 26, 689-695, 2001.

Qi, Y., Matsuda, S., Kikuchi, T., and Ohtoshi, K.: A possibility of utilization of GMS-5 infrared brightness data as information of disaster prevention for a localized heavy rainfall, J. Japan Society for Natural Disaster Science, 20, 173-182, 2001.

Rickenmann, D.: Bedload transport and discharge in the Erlenbach stream, in: Dynamics and Geomorphology of Mountain Rivers, edited by: Ergensinger, P. and Schmidt, K. H., 52, 53-66, 1994.

Rickenmann, D., D’Agostino, V., Fontana, G. D., Lenzi, M., and Marchi, L.: New results from sediment transport measurements in two alpine torrents, Hydrology, Water Resources and Ecology in Headwaters, Proc. Head Water '98 Conf., Meran/Merano, Italy, April 1998, IAHS Publication No. 248, 283-289, 1998.

Rickenmann, D.: Comparison of bed load transport in torrents and gravel bed streams, Water Resources Res., 37, 3295-3305, 2001

Suwa, H. and Okuda, S.: Measurement of debris flows in Japan, Proc. IV th Intern. Conf. And Field Workshop on Landslides, Tokyo, Aug. 1985, 391-400, 1985.

Suwa, H, Yamakoshi, T., and Sato, K.: Relationship between debris-flow discharge and ground vibration, in: Debris-Flow Hazards Mitigation: Mechanics, Prediction, and Assessment, edited by: Wieczorek, G. F. and Naeser, N. D., Proc. 2nd Intern. Conf., Taipei, Taiwan, 16-18 August 2000, Rotterdam, Balkema Press, 311-318, 2000.

Tanabashi, Y.: Risk assessment and prediction of debris flow occurrence, J. Japan Society for Natural Disaster Science, 16, 293 306, 1998. 
Taniguchi, S., Itakura, Y., Miyamoto, K., and Kurihara, J.: A new acoustic sensor for sediment discharge measurement, in: Erosion and Sediment Transport Monitoring Programmes in River Basin, Bogen, J., Walling, D. E., and Day, T., Proc. Intern. Symp., Oslo, Norway, 24-28 August 1992, IAHS Publication No. 210, 135$142,1992$.

Temesgen, B., Mohammed, M. U., and Korme, T.: Natural hazard assessment using GIS and remote sensing methods, with particular reference to the landslides in the Wondongenet area, Ethiopia, Phys. Chem. Earth (C), 26, 665-675, 2001.

Uddin, M. S., Inaba, H., Itakura, Y., and Kasahara, M.: Estimation of the surface velocity of debris-flow with computer-based spatial filtering, Appl. Opt., 37, 6234-6239, 1998.

Uddin, M. S., Inaba, H., Itakura, Y., Yoshida, Y., and Kasahara, M.: Adaptive computer-based spatial filtering method for more accurate estimation of the surface velocity of debris-flow, Appl. Opt., 38, 6714-6721, 1999.

Uddin, M. S., Inaba, H., Itakura, Y., Yoshida, Y., and Kasahara, M.: Large motion estimation by gradient technique-Application to debris-flow velocity field, Phys. Chem. Earth (C), 26, 633638,2001

Uddin, M. S., Inaba, H., Yoshida, Y., and Itakura, Y.: Debris flow velocity estimation: a comparison between gradient-based method and cross-correlation method, Image Processing: Algorithms and Systems, Proc. SPIE, 21-23 January 2002, SPIE No. 4667, 130-136, 2002.
Wieczorek, G. F., Coe, J. A., and Godt, J. W.: Remote sensing of rainfall for debris-flow hazard assessment, in: Debris-Flow Hazards Mitigation: Mechanics, Prediction, and Assessment, Rickenmann, D. and Wieczorek, G. F., Proc. 3rd Intern. Conf., Davos, Switzerland, 10-12 Sept. 2003, Rotterdam, Mill Press, 12571268, 2003.

YDK: Catalog No. J7641 and K 2000. Yokogawa Denshikiki Co., Ltd., Nishishinjyuku 3-7-1, Shinjyuku-ku, Tokyo 163-1054, Japan,, (http://www.yokogawa.co.jp/YDK/), 2002.

Zhang, S.: A Comprehensive approach to the observation and prevention of debris flows in China, Nat. Haz., 7, 1-23, 1993.

Zhang, S. and Chen J.: Measurement of debris-flow surface characteristics through close-range photogrammetry, in: Debris-Flow Hazards Mitigation: Mechanics, Prediction, and Assessment, edited by: Rickenmann, D. and Wieczorek, G. F., Proc. 3rd Intern. Conf., Davos, Switzerland, 10-12 Sept. 2003, Rotterdam, Mill Press, 775-784, 2003.

Zhang, S., Hong, Y., and Yu, B.: Detecting infrasound emission of debris flows for warning purposes, Proc. 10 Congress INTERPRAEVENT 2004, Riva del Garda, Trento, Italy, 24-27 May 2004, Z/359-Z/364, 2004.

Zhicheng, K. and Pinghua, H.: A debris flow mud-level alarm and its principle, in: Landslides and Debris-Flows, edited by: Tochiki, S., Proc. The Japan-China Symposium, 3 Oct., Niigata and 5 Oct., Tokyo, Japan, 1989, published by The Japan Landslide Soc. and The Japan Soc. Erosion Control Eng., 209-212, 1989. 